\title{
PENERAPAN STRATEGI PROMOSI MELALUI SISTEM TELEMARKETING (Studi Kasus: Pameran Bandung INAFACT 2017)
}

\author{
Ranny Hanartani ${ }^{1}$, Maswir., S.E. M.M. ${ }^{2}$ \\ ${ }^{1}$ Program Studi MICE - Politeknik Negeri Jakarta, rhanartani@yahoo.co.id \\ 2 Program Stydi MICE - Politeknik Negeri Jakarta, mawi.maswir@ yahoo.co.id
}

\begin{abstract}
Bitter competition in goods and services marketing trigger company to more responsive to the fast-changing market which is really fast and firm must be able to find the right marketing strategies. As in business competition that occurs in MICE industry is really competitive. Its is encouraged new event organizer companies that ready to compete in provided their own prominence. No exception for PT. Produta Promosindo. One of the marketing strategy that used is telemarketing. This study used qualitative methods. Aims to identify and analyze the implementation of promosting strategies by telemarketing system that used by PT. Produta Promosindo. This study shows that telemarketing strategy cannot be said succesfull or not in attracted customer interested.
\end{abstract}

Keyword : promotion, promotion strategies, telemarketing

\begin{abstract}
ABSTRAK
Persaingan sengit dalam pemasaran produk barang dan jasa memicu perusahaan untuk lebih tanggap terhadap perubahan pasar yang sangat cepat dan perusahaan harus dapat melaksanakan strategi yang tepat. Seperti pada persaingan bisnis yang terjadi pada industri MICE (Meeting, Incentive, Conference and Exhibition) sekarang dapat dibilang cukup ketat. Hal ini mendorong munculnya perusahaan event organizer baru yang siap bersaing dalam memberikan keunggulannya masing-masing. Tak terkecuali PT. Produta Promosindo. Salah satu strategi pemasaran yang digunakan adalah telemarketing. Penelitian ini dilakukan dengan metode kualitatif. Penelitian ini bertujuan untuk mengetahui dan menganalisa penerapan strategi promosi melalui sistem telemarketing yang digunakan oleh PT. Produta Promosindo. Adapun metode pengumpulan data yang digunakan yaitu observasi dan wawancara. Penelitian ini menunjukkan bahwa tahapan sistem promosi sebuah pameran dengan menggunakan telemarketing adalah membuat database, memperbarui database, dan melakukan proses penelponan. Hasil penelitian ini menunjukkan bahwa strategi promosi melalui telemarketing belum dapat dikatakan berhasil atau tidak dalam menarik minat konsumen.
\end{abstract}

Kata kunci: promosi, strategi promosi, telemarketing 


\section{PENDAHULUAN}

Persaingan sengit dalam pemasaran produk barang dan jasa memicu perusahaan untuk lebih tanggap terhadap perubahan pasar yang sangat cepat. Begitu pula hal nya dengan dunia MICE (Meeting, Incentive, Convention, and Exhibition) yang mengalami perkembangan yang sangat pesat. Maka perlu adanya strategi untuk dapat tetap bertahan dan berkembang dalam menghadapi para pesaing. Dan juga tetap harus memperhatikan sikap dan perilaku yang sedang trend di kalangan konsumen. Perilaku konsumen di masa modern ini lebih menginginkan sesuatu yang bersifat efisien dan efektif. Salah satu cara yang dilakukan PT. Produta Promosindo adalah dengan sistem pemasaran melalui telemarketing. Telemarketing sebagai bentuk program komunikasi persuasif kepada khalayak sasaran secara berkelanjutan dan dapat menghubungkan khalayak sasaran dengan produk/jasa yang ditawarkan, dengan demikian komunikasi pemasaran akan menciptakan peluang terjadinya fasilitasi yang saling memuaskan.

Banyak nya penggunaan telemarketing saat ini antara lain disebabkan oleh biaya yang relatif rendah dibandingkan dengan promosi dengan cara yang lain. Penjualan pribadi begitu mahal, namun sangat persuasif. Telemarketing hampir memiliki tingkat persuasi yang sama, namun jauh lebih rendah biayanya (Lee \& Johnson, 2007:67).

Membandingkan komunikasi yang digunakan dalam pemasaran langsung tatap muka dan melalui telepon, komunikasi tatapmuka ini membuat manusia merasa lebih akrab dengan sesamanya, berbeda dengan komunikasi lewat media massa seperti surat kabar, televisi, atau lewat teknologi komunikasi tercanggih sekalipun seperti telepon genggam, E-mail, atau telekonferensi, yang membuat manusia merasa terasing (Mulyana, 2010:81)

seorang telemarketer bahkan belum mengenal secara intim calon konsumen yang hendak diajak berbicara untuk menawarkan produknya. Bahkan, admin mendapat nomor telepon sasaran calon konsumennya secara acak, hanya dari browsing melalui mesin pencari atau dari rekomendasi member yang sudah bergabung sebelumnya. Inilah yang menjadi tantangan telemarketer bagaimana strategi komunikasi yang digunakan sehingga calon konsumen bertahan untuk mendengarkan "orang asing" berbicara melalui telepon bahkan tertarik dengan produk yang ditawarkan.

Maka dari itu, muncul permasalahan bagaimana strategi komunikasi melalui telepon yang digunakan oleh telemarketer PT. Produta sehingga lebih banyak menarik konsumen untuk menjadi exhibitor pada Bandung INAFACT 2017. Sedangkan dikatakan sebelumnya bahwa komunikasi interpersonal secara langsung dengan tatap muka merupakan komunikasi yang paling efektif untuk membujuk karena kita dapat menggunakan kelima alat indera kita agar pesan tersampaikan kepada komunikan

Dari uraian yang telah diuraikan diatas, hal ini merupakan faktor-faktor yang melatarbelakangi peneliti untuk menelaah mengenai seluk beluk telemarketing secara lebih mendalam pada penyelenggaraan event Bandung INAFACT

2017

\section{METODE PENELITIAN}

Metode penelitian yang digunakan oleh penulis adalah metode action research (penelitian tindakan) yaitu melakukan penelitian terhadap pekerjaan yang sudah dilakukan selama praktik kerja lapangan. 


\section{HASILDAN PEMBAHASAN}

Proses melakukan kegiatan telemarketing yang digunakan oleh PT. Produta Promosindo adalah sebagai berikut:

1. Mencari database calon exhibitor

2. Melakukan update database

3. Melakukan proses penelponan

4. Mengirim brosur bagi calon exhibitor yang tertarik

5. Mengirimkan formulir pendaftaran bagi yang mendaftarkan diri sebagai exhibitor.

Dari hasil pencarian database terdapat 477 instansi pemerintahan yang akan dihubungi. Berikut adalah tabelnya:

Tabel1.1

Rekapitulasi Database Calon Exhibitor berdasarkan wilayahnya

\begin{tabular}{|c|l|c|}
\hline NO & \multicolumn{1}{|c|}{ WILAYAH } & JUMLAH \\
\hline 1 & YOGYAKARTA & 22 \\
\hline 2 & SUMATERA SELATAN & 19 \\
\hline 3 & SULAWESI TENGGARA & 12 \\
\hline 4 & SULAWESI TENGAH & 12 \\
\hline 5 & SULAWESI BARAT & 8 \\
\hline 6 & SULAWESISELATAN & 31 \\
\hline 7 & SULAWESIUTARA & 29 \\
\hline 8 & NUSA TENGGARA TIMUR & 46 \\
\hline 9 & NUSA TENGGARA BARAT & 34 \\
\hline 10 & KALIMANTAN TIMUR & 14 \\
\hline 11 & KALIMANTAN SELATAN & 19 \\
\hline 12 & JAWA BARAT & 100 \\
\hline 13 & BALI & 52 \\
\hline 14 & LAMPUNG & 13 \\
\hline 15 & MALUKUUTARA & 11 \\
\hline 16 & DKI JAKARTA & 7 \\
\hline 17 & RIAU & 45 \\
\hline \multicolumn{2}{|l|}{ TOTAL } & 477 \\
\hline
\end{tabular}

Sumber : hasil olahan data

Dari proses penelponan penulis mendapatkan data jumlah calon exhibitor yang tertarik, tidak tertarik, juga yang nomornya tidak tersambung pada saat dilakukan penelponan. Berikut ini adalah tabelnya:
Tabel 1.2

Rekapitulasi Final Database dari

Respon Telemarketing

\begin{tabular}{|c|l|c|c|c|}
\hline NO & \multicolumn{1}{|c|}{ REGION } & INTERESTED & $\begin{array}{c}\text { NOT } \\
\text { INTERESTED }\end{array}$ & $\begin{array}{c}\text { NOT } \\
\text { CONNECTED }\end{array}$ \\
\hline 1 & YOGYAKARTA & 16 & 0 & 6 \\
\hline 2 & SUMATERASELATAN & 5 & 4 & 10 \\
\hline 3 & SULAWESI TENGGARA & 5 & 2 & 5 \\
\hline 4 & SULAWESI TENGAH & 6 & 0 & 6 \\
\hline 5 & SULAWESI BARAT & 3 & 3 & 2 \\
\hline 6 & SULAWESI SELATAN & 2 & 0 & 29 \\
\hline 7 & SULAWESIUTARA & 7 & 1 & 21 \\
\hline 8 & NUSA TENGGARA TIMUR & 9 & 6 & 31 \\
\hline 9 & NUSA TENGGARA BARAT & 9 & 7 & 18 \\
\hline 10 & KALIMANTAN TIMUR & 5 & 3 & 6 \\
\hline 11 & KALIMANTAN SELATAN & 3 & 3 & 13 \\
\hline 12 & JAWA BARAT & 33 & 15 & 52 \\
\hline 13 & BALI & 10 & 13 & 29 \\
\hline 14 & LAMPUNG & 5 & 3 & 5 \\
\hline 15 & MALUKUUTARA & 3 & 2 & 6 \\
\hline 16 & DKI JAKARTA & 2 & 0 & 5 \\
\hline 17 & RIAU & 7 & 0 & 282 \\
\hline & TOTAL & 130 & 62 & \\
\hline
\end{tabular}

Sumber : hasil olahan data

Gambar 1.1

Grafik Perbandingan Database Calon Exhibitor yang Interested, Not Interested, dan Not Connected

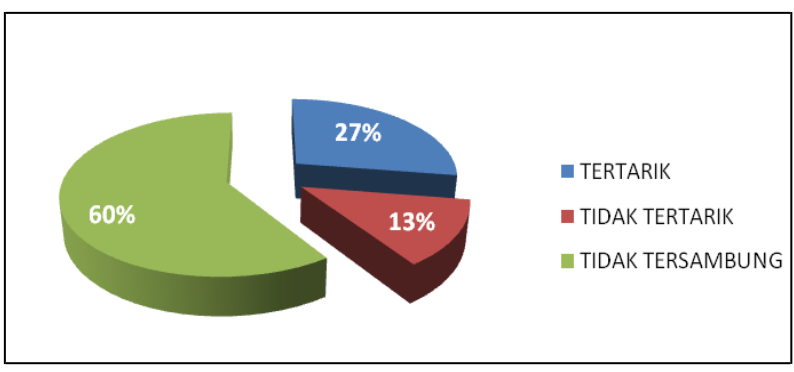

Sumber : hasil olahan data

Grafik diatas menunjukkan bahwa persentase calon exhibitor yang tertarik dengan Pameran Bandung INAFACT hanya sebesar

$27 \%$ dengan data sebanyak 130 instansi, tidak tertarik sebesar $13 \%$ dengan data sebanyak 62 instansi, dan nomor yang tidak tersambung dengan persentase terbesar yaitu $60 \%$ dengan data sebanyak 282 instansi. Maka dapat penulis simpulkan bahwa database calon 
exhibitor yang dimiliki oleh PT. Produta Promosindo terlalu luas, karena hampir setengah dari total keseluruhan database tidak dapat dihubungi.

Nomor-nomor yang tidak dapat dihubungi ini sebagian besar penulis dapatkan dengan mencari dari website instansi terkait. Dan setelah dilihat ternyata website tersebut terakhir di perbaharui sudah sangat lama. Sehingga kemungkinan nomor telepon nya sudah berganti atau sudah tidak aktif lagi.

Dari data calon exhibitor yang tertarik penulis kembali mengerucutkan database dengan membagi data menjadi dua yaitu yang ikut dan tidak ikut pameran ini dengan membuatnya dalam bentuk persentase. Berikut adalah tabelnya:

Tabel 1.3

Rekapitulasi total yang ikut dan tidak ikut pameran Bandung INAFACT 2017

\begin{tabular}{|c|l|c|c|c|c|c|}
\hline \multirow{2}{*}{ NO } & \multirow{2}{*}{ WILAYAH } & \multicolumn{5}{|c|}{ TERTARIK } \\
\cline { 3 - 7 } & & JUMLAH & IKUT & $(\%)$ & $\begin{array}{c}\text { TIDAK } \\
\text { IKUT }\end{array}$ & \multirow{2}{*}{$\%)$} \\
\hline 1 & YOGYAKARTA & 16 & 1 & 6.25 & 15 & 13.2 \\
\hline 2 & SUMATERASELATAN & 5 & 1 & 6.25 & 4 & 3.51 \\
\hline 3 & SULAWESI TENGGARA & 5 & 0 & 0 & 5 & 4.39 \\
\hline 4 & SULAWESI TENGAH & 6 & 0 & 0 & 6 & 5.26 \\
\hline 5 & SULAWESI BARAT & 3 & 0 & 0 & 3 & 2.63 \\
\hline 6 & SULAWESISELATAN & 2 & 0 & 0 & 2 & 1.75 \\
\hline 7 & SULAWESIUTARA & 7 & 1 & 6.25 & 6 & 5.26 \\
\hline 8 & NUSA TENGGARATIMUR & 9 & 0 & 0 & 9 & 7.89 \\
\hline 9 & NUSA TENGGARA BARAT & 9 & 0 & 0 & 9 & 7.89 \\
\hline 10 & KALIMANTAN TIMUR & 5 & 1 & 6.25 & 4 & 3.51 \\
\hline 11 & KALIMANTAN SELATAN & 3 & 1 & 6.25 & 2 & 1.75 \\
\hline 12 & JAWA BARAT & 33 & 7 & 43.8 & 26 & 22.8 \\
\hline 13 & BALI & 10 & 0 & 0 & 10 & 8.77 \\
\hline 14 & LAMPUNG & 5 & 1 & 6.25 & 4 & 3.51 \\
\hline 15 & MALUKUUTARA & 3 & 1 & 6.25 & 2 & 1.75 \\
\hline 16 & DKI JAKARTA & 2 & 1 & 6.25 & 1 & 0.88 \\
\hline 17 & RIAU & 7 & 1 & 6.25 & 6 & 5.26 \\
\hline & \multicolumn{1}{|c|}{ JUMILAH } & 130 & 16 & & 114 & \\
\hline
\end{tabular}

Sumber : hasil olahan data 
Menurut data diatas, jumlah exhibitor yang tertarik untuk mengikuti Pameran bandung INAFACT 2017 adalah sejumlah 130 instansi atau sebesar $27 \%$ dengan rincian 16 instansi yang ikut \& 114 instansi yang tidak ikut sebagai peserta (exhibitor). Pesentase terbesar yang ikut pameran ini terdapat pada wilayah Jawa Barat dengan persentase sebesar $43 \%$.

\section{KESIMPULAN}

Berdasarkan hasil penelitian yang telah dilakukan dengan action research dalam pelaksanaan kegiatan telemarketing sudah berjalan sesuai dengan prosedur yang semestinya. Namun pada database terdapat banyak informasi yang tidak akurat. Hal ini ditunjukkan dengan banyaknya calon exhibitor yang tidak mengangkat atau nomornya tidak tersambung.

Sistem promosi event dengan menggunakan sistem telemarketing belum dapat diukur keberhasilannya dalam meningkatkan daya tarik calon exhibitor. Karena hamper setengah persen tidak tersambung dan tidak mengangkat telepon saat dihubungi. Hal ini karena banyak nomor telepon yang terdapat dalam database sudah tidak aktif dan sudah berganti.

Dari keseluruhan database yang dihubungi menunjukkan bahwa persentase calon exhibitor yang tertarik dengan Pameran Bandung INAFACT jika dilihat berdasarkan wilayahnya lebih banyak yang tertarik dengan pameran ini berasal dari tempat event diselenggarakan yaitu wilayah Jawa Barat.

\section{SARAN}

Karena tingginya angka calon exhibitor yang tidak menjawab telepon maka perlu di dukung dengan adanya informasi secara tertulis misalnya melalui sebuah website atau e-mail. Sehingga bagi instansi yang tadinya tidak mengangkat telepon atau ada informasi yang terlewat bisa mendapatkan informasi lebih detail melalui website tersebut. Selain itu manfaat jika PT. Produta Promosindo membuat suatu website adalah dapat digunakan untuk melakukan sistem registrasi online untuk event- event mendatang.

Karena banyaknya nomor telepon yang tidak akurat maka perlu adanya kegiatan memperbarui database dengan cara melakukan survei langsung ke instansi yang terkait untuk mendapatkan data yang benarbenar terbaru.

Sebelum melakukan kegiatan penelponan seharusnya dilakukan identifikasi terhadap instansi-instansi yang berpotensial. Misalnya klasifikasikan berdasarkan daerah dari calon exhibitor berasal. Utamakan yang ditelepon adalah instansi yang dekat dengan tempat penyelenggaraan event.

\section{DAFTAR PUSTAKA}

Alma, Buchari. 2013. Manajemen Pemasaran dan Pemasaran Jasa, Bandung: Alfabeta.

Chantika, Dea. 2013. Pengaruh Direct Marketing Terhadap Keputusan Menggunakan Meeting Package di Mitra Hotel Bandung: Bandung.

Daryanto. 2011. Sari Kuliah Manajemen Pemasaran Bandung: PT Sarana Tutorial Nurani Sejahtera

Dewi, Nurmala dan Ridwan Purnama. 2013. Pengaruh Direct Mail dan Telemarketing Terhadap Keputusan Pembelian Paket Umrah raka Tours and Travel. Bandung: Tourism and 
Hospitality Essentials Journal. Vol.III, No.2:7-8

Djaslim, Saladin. 2004. Manajemen Pemasaran Analisis, Perencanaan, Pelaksanaan, dan Pengendalian. Bandung: Linda Karya

Kotler dan Keller. 2009. Manajemen Pemasaran, Edisi Ketiga Belas, Jilid 1, dialihbahasakan oleh Bob, Jakarta: Erlangga

Lupiyoadi. 2013. Manajemen Pemasaran Jasa. Jakarta: Selemba Empat

Shinta, Agustina. 2011. Manajemen Pemasaran. Malang: Universitas Brawijaya Press. 